\title{
Consumo e digestibilidade de nutrientes de dietas com silagens de grãos úmidos de milho ou sorgo, em ovinos
}

[Intake and digestibility of nutrients in sheep diets based on corn and sorghum grain high moisture silages]

\author{
C.C.B.F. Ítavo ${ }^{1}$, M.G. Morais ${ }^{1}$, L.C.V. Itavo ${ }^{2}$, A.R.D.L. Souza ${ }^{3}$, F.C.A. Davy ${ }^{3}$, F.A. Biberg ${ }^{3}$, \\ W.B. Alves ${ }^{3}$, M.V. Santos ${ }^{3}$ \\ ${ }^{1}$ Faculdade de Medicina Veterinária e Zootecnia - UFMS \\ Caixa Postal 549 \\ 79070-900 - Campo Grande, MS \\ ${ }^{2}$ Universidade Católica Dom Bosco - Campo Grande, MS - Bolsista do CNPq \\ ${ }^{3}$ Zootecnista autônomo
}

\begin{abstract}
RESUMO
Avaliaram-se o consumo, a digestibilidade e o teor de nutrientes digestíveis totais (NDT) de dietas contendo silagens de grãos úmidos de milho e de sorgo, com ou sem inoculante microbiano, em ovinos. O volumoso utilizado foi feno de capim-braquiária (Brachiaria brizantha cv. Marandu). Doze animais foram distribuídos em quatro tratamentos: (1) feno+silagem de grão úmido de milho, (2) feno+silagem de grão úmido de sorgo; (3) feno+silagem de grão úmido de milho com inoculante microbiano e (4) feno+silagem de grão úmido de sorgo com inoculante microbiano. Não houve diferença entre tratamentos quanto aos consumos de matéria seca, de matéria orgânica, de proteína bruta, de fibra em detergente neutro, de carboidratos totais e de carboidratos não estruturais. $\mathrm{O}$ consumo de extrato etéreo diferiu em função do tipo de grão. Não houve diferença entre tratamentos quanto à digestibilidade dos nutrientes. Não houve efeito do grão e da inoculação para o NDT estimado das silagens de grãos úmidos de milho e de sorgo, com médias de $77,6 \%$ e $79,5 \%$, respectivamente. O uso de inoculante microbiano em silagens de grãos úmidos não se fez necessário. O grão de milho úmido pode ser substituído pelo de sorgo sem prejuízos ao aproveitamento de nutrientes em ovinos adultos.
\end{abstract}

Palavras-chave: grão úmido, inoculante, milho, silagem, sorgo

\begin{abstract}
The intake, the digestibility of nutrients, and the total digestible nutrients (TDN) content in sheep diets based on corn and sorghum grains high moisture silages with or without microbial inoculant, were evaluated. The used roughage was Brachiaria hay (Brachiaria brizantha $c v$. Marandu). Twelve animals were distribuited to treatments: (1) hay+high moisture corn grain silage, (2) hay+high moisture sorghum grain silage; (3) hay+high moisture corn grain silage with microbial inoculant, and (4) hay+high moisture sorghum grain silage with microbial inoculant. No differences among treatments in relation to the intake of dry matter, organic matter, crude protein, neutral detergent fiber, and total and nonstructural carbohydrates were observed. The ether extract intake differed according to the grains. The silages did not differ in relation to the estimated digestibilities for dry matter, organic matter, crude protein, neutral detergent fiber, ether extract, and total and non-structural carbohydrates. The TDN did not differ according to the grains and inoculant, with averages of 77.6 and $79.5 \%$, for corn and sorghum grains high moisture silages, respectively. It was demonstrated that the use of microbial inoculant, in high moisture grain silages was not necessary. High moisture corn grain silage can be substituted by high moisture sorghum grain silage without effects on the use of nutrients by sheep.
\end{abstract}

Keywords: corn, high moisture, inoculant, silage, sorghum

Recebido em 11 de setembro de 2008

Aceito em 16 de março de 2009

E-mail: camilaitavo@nin.ufms.br 


\section{INTRODUÇÃO}

Existem vantagens na ensilagem de grãos úmidos (Jobim et al., 2001), como maximização do uso da terra, por meio da colheita antecipada, redução de perdas quantitativas e qualitativas no campo e na armazenagem, menor tombamento de plantas por ataque de pássaros, insetos e doenças, e econômica, devido à eliminação das etapas de pré-limpeza e secagem (Costa et al., 1999; Jobim e Reis, 2001).

Grãos úmidos apresentam bom potencial de utilização no processo de ensilagem. Jobim e Reis (2001), em revisão, apresentaram algumas desvantagens quanto à sua adoção, já que o material ensilado não possui flexibilidade de comercialização, é sensível à deterioração aeróbia e necessita de mistura diária dos ingredientes na composição da dieta.

Henderson (1993) citou que a inoculação poderia resultar em melhor desempenho animal devido ao aumento de consumo de nutrientes advindos de uma silagem bem conservada. Jobim e Reis (2001) citaram que a maior relação ácido láctico:acético poderia favorecer a ingestão de matéria seca, devido ao efeito negativo do ácido acético sobre a aceitabilidade da forragem conservada. Segundo Vilela (1998), a inoculação apresentou resultados mínimos, com melhoras entre 2 e 4\% sobre o consumo de silagem. Silagens da parte aérea do milho inoculadas, em dietas para ovinos confinados, promoveram maior aceitabilidade e diminuição do tempo necessário para terminação (Meeske e Basson, 1998). Rodrigues et al. (2002) não recomendaram a inoculação para ensilagem da parte aérea de milho, uma vez que não houve aumento na disponibilidade de nutrientes ou consumo de matéria seca. Vieira et al. (2004) estudaram o efeito da inoculação na ensilagem da parte aérea de diferentes híbridos de sorgo e não verificaram aumento nos valores de digestibilidade in vitro da matéria seca (DIVMS) de silagens dos híbridos BR 701, BR 601 e AG 2002, com exceção da silagem de parte aérea do híbrido BR 700 de sorgo, que apresentou maior DIVMS com a inoculação.

Schaefer et al. (1989) estudaram o efeito da inoculação em silagens de parte aérea e de grãos úmidos de milho e verificaram que as silagens de grãos úmidos foram mais responsivas à adição de inoculante quanto ao processo fermentativo, sem diferenças no consumo de matéria seca e digestibilidade de fibra em detergente neutro e proteína bruta por novilhos. Ítavo et al. (2003) avaliaram a DIVMS de silagens de grãos úmidos de milho, inoculadas ou não, e encontraram maior digestibilidade para silagens inoculadas.

Phillip e Fellner (1992) avaliaram a digestibilidade de dietas contendo silagens de grãos úmidos de milho, em $20 \%$ da MS, inoculadas ou não, consumidas por novilhos, e verificaram efeito negativo de um dos inoculantes comerciais, à base de Lactobacillus plantarum, sobre a digestibilidade da fibra em detergente ácido.

Passini et al. (2002), ao estudarem a digestibilidade em bovinos, verificaram que a substituição dos grãos úmidos de milho pelos de sorgo diminuiu linearmente o teor de nutrientes digestíveis totais. Passini et al. (2003) encontraram semelhante produção de ácidos graxos totais e $\mathrm{pH}$ ruminal, o que foi atribuído à colheita precoce dos grãos úmidos.

O objetivo do presente trabalho foi avaliar o consumo, a digestibilidade de nutrientes e o teor de nutrientes digestíveis totais de dietas contendo feno de capim-braquiária (Brachiaria brizantha $\mathrm{cv}$. MG4) e silagens de grãos úmidos de milho e de sorgo com ou sem inoculante microbiano, em ovinos.

\section{MATERIAL E MÉTODOS}

O plantio do sorgo (cv. Rancheiro) e do milho (associação de híbridos comerciais) foi realizado em março de 2003, e a colheita e a ensilagem ocorreram em julho do mesmo ano. O milho e o sorgo foram colhidos na fase de maturação fisiológica do grão, com teores de matéria seca de 63,7 e $66,0 \%$, respectivamente. O inoculante foi adicionado de forma homogênea, por aspersão, de acordo com as recomendações do fabricante. $\mathrm{O}$ inoculante microbiano utilizado foi o Biomax ${ }^{\circledR}$ milho e sorgo ${ }^{1}$, tendo como principal microrganismo Lactobacillus plantarum. $\mathrm{O}$ material processado foi ensilado em três tambores plásticos, tipo tonel, com capacidade de $200 \mathrm{~L}$, por tratamento, totalizando 12 silospiloto. As silagens permaneceram vedadas, em

${ }^{1}$ Katec, Aparecida de Goiânia, Brasil. 
local coberto e à temperatura ambiente, por 64 dias.

Foram utilizados 12 ovinos, castrados, adultos, sem raça definida, com peso médio de $39,96 \pm 3,08 \mathrm{~kg}$, em ensaio de digestibilidade aparente pelo método de coleta total de fezes. Os animais tosquiados, vermifugados, de acordo com as análises de ovos por grama de fezes e casqueados, foram mantidos em gaiolas metabólicas providas de comedouro e bebedouro, com acesso irrestrito à água e à mistura mineral.

Para as estimativas de digestibilidade, utilizou-se o método da digestibilidade por diferença (Silva e Leão, 1979), no qual os coeficientes de digestibilidade do alimento base são determinados antecipadamente (primeiro período), com posterior adição do alimento objeto do estudo (segundo período). No primeiro período, forneceu-se a todos os animais exclusivamente feno de capim-braquiária. No segundo período, os animais foram distribuídos em blocos ao acaso, por peso, com três animais por tratamento: (1) feno + silagem de grão úmido de milho; (2) feno + silagem de grão úmido de sorgo; (3) feno + silagem de grão úmido de milho com inoculante microbiano e (4) feno + silagem de grão úmido de sorgo com inoculante microbiano, oferecidos na proporção de $40 \%$ de feno e $60 \%$ de silagem, com base na matéria seca. A alimentação foi fornecida diariamente às $8 \mathrm{~h}$, ad libitum, de forma a permitir sobras aproximadas de $10 \%$ do oferecido. A composição do feno e a das silagens são apresentadas na Tab. 1.

Tabela 1. Teores de nutrientes do feno de capim-braquiária (Brachiaria brizantha cv. MG4) e das silagens de grãos úmidos de milho e de sorgo, com ou sem inoculante microbiano

\begin{tabular}{lrcccc}
\hline \multirow{2}{*}{ Nutriente } & \multirow{2}{*}{ Feno } & \multicolumn{4}{c}{ Silagem de grãos úmidos } \\
\cline { 3 - 6 } & & sem inoculante & com inoculante & sem inoculante & com inoculante \\
\cline { 3 - 6 } & 87,51 & 63,63 & 63,78 & 66,58 & 65,46 \\
\hline MS (\%) & 90,51 & 98,71 & 98,74 & 98,40 & 98,20 \\
MO (\%MS) & 3,24 & 6,72 & 7,04 & 6,94 & 7,17 \\
PB (\%MS) & 1,13 & 3,61 & 3,57 & 2,23 & 2,23 \\
EE (\%MS) & 79,88 & 23,41 & 23,46 & 20,63 & 20,64 \\
FDN (\%MS) & 6,27 & 64,98 & 64,66 & 68,60 & 68,15 \\
CNE (\%MS) & 86,15 & 88,39 & 88,12 & 89,23 & 88,79 \\
CHOT (\%MS)
\end{tabular}

MS: matéria seca; MO: matéria orgânica; PB: proteína bruta; EE: extrato etéreo; FDN: fibra em detergente neutro; CNE: carboidratos não estruturais; CHOT: carboidratos totais.

Antes do fornecimento, os alimentos foram misturados. O consumo foi determinado pela diferença entre a quantidade de alimento fornecido e as sobras. Os animais foram pesados ao início e ao final de cada período experimental. Após 10 dias de adaptação à dieta e às bolsas coletoras, realizaram-se coletas totais de fezes, durante cinco dias, manualmente retiradas antes da alimentação, homogeneizadas e amostradas $10 \%$ do total excretado. Diariamente, os alimentos, as sobras e as fezes foram quantificados, colhendo-se $10 \%$ do total para elaboração de amostras compostas, que foram armazenadas em sacos plásticos identificados e congelados a $-20^{\circ} \mathrm{C}$ para posteriores análises.

Os cálculos dos coeficientes para digestibilidade da matéria seca (MS), matéria orgânica (MO), proteína bruta $(\mathrm{PB})$, fibra em detergente neutro (FDN), extrato etéreo (EE) e carboidratos totais
(CHOT) e não estruturais (CNE) das dietas e as estimativas de digestibilidade das silagens foram realizados segundo Silva e Leão (1979), com base na relação entre ingestão e produção fecal.

As amostras foram pré-secas em estufa de ventilação forçada, a $55^{\circ} \mathrm{C}$, por 96 horas, e moídas em crivos de $1 \mathrm{~mm}$. As amostras de silagens, feno, sobras e fezes foram avaliadas quanto aos teores de MS, MO, EE, PB e FDN, conforme as técnicas descritas por Silva e Queiroz (2002).

Os CHOT foram obtidos por intermédio da equação: 100 - (\%PB + \%EE + \%Cinzas $)$, e os teores de CNE e NDT foram obtidos segundo Sniffen et al. (1992).

O delineamento utilizado foi em blocos ao acaso, com quatro tratamentos e três repetições por 
tratamento. Os dados de consumo e digestibilidade dos nutrientes, assim como os teores de nutrientes digestíveis totais, foram arranjados em esquema fatorial $2 \times 2$ (milho ou sorgo, com ou sem inoculante) e avaliados por meio de análises de variância, sendo as médias comparadas pelo teste Tukey, em nível de 5\% de significância.

\section{RESULTADOS E DISCUSSÃO}

As médias de consumo e a digestibilidade dos nutrientes do feno de capim-braquiária são apresentadas na Tab. 2. O feno utilizado pode ser considerado de baixa qualidade, identificado pelos valores de PB e FDN apresentados na Tab. 1, bem como da reduzida digestibilidade aparente da MS, MO, PB, FDN e NDT (Tab. 2).

As médias de consumo dos nutrientes das dietas, em função dos tratamentos, são apresentadas na
Tab. 3. Não houve interação significativa $(\mathrm{P}>0,05)$ de dietas contendo feno de capimbraquiária versus silagem de grãos úmidos de milho e de sorgo com ou sem inoculante microbiano. Não foram detectadas diferenças entre tratamentos no consumo de nutrientes, exceto no consumo de EE, maior nas dietas com silagem de grãos úmidos de milho, o que está relacionado à maior porcentagem de EE desse ingrediente (Tab. 1).

As médias de CMS das dietas com silagens de grãos úmidos de milho ou de sorgo foram, respectivamente, de 796,65 e 727,00g/dia (Tab. 3 ), ligeiramente maiores que os $713,4 \mathrm{~g} / \mathrm{dia}$ de Rodrigues et al. (2002), que também não verificaram efeitos da inoculação na ensilagem da parte aérea de milho sobre consumo por ovinos.

Tabela 2. Médias e erro-padrão das médias de consumo e coeficientes de digestibilidade aparente dos nutrientes do feno de capim-braquiária (Brachiaria brizantha cv. MG4) usado para ovinos

\begin{tabular}{lccccc} 
Variável & Consumo (g/dia) & CV $(\%)$ & & Digestibilidade $(\%)$ & CV $(\%)$ \\
\hline MS & $814,27 \pm 45,30$ & 19,27 & & $28,63 \pm 1,96$ & 23,83 \\
MO & $734,44 \pm 40,69$ & 19,19 & & $35,10 \pm 1,71$ & 16,94 \\
PB & $27,52 \pm 1,68$ & 19,69 & & $27,16 \pm 7,58$ & 26,06 \\
EE & $9,54 \pm 1,57$ & 20,08 & & $82,21 \pm 1,95$ & 21,10 \\
FDN & $646,74 \pm 38,51$ & 19,20 & & $39,03 \pm 2,63$ & 13,90 \\
CNE & $50,65 \pm 1,43$ & 19,05 & & $99,00 \pm 0,41$ & 3,90 \\
CHOT & $697,38 \pm 8,69$ & 19,17 & & $43,46 \pm 2,34$ & 11,58 \\
NDT & $329,66 \pm 23,34$ & 23,21 & & $40,30 \pm 2,51$ & 10,70 \\
\hline
\end{tabular}

MS: matéria seca; MO: matéria orgânica; PB: proteína bruta; EE: extrato etéreo; FDN: fibra em detergente neutro; CNE: carboidratos não estruturais; CHOT: carboidratos totais; NDT: nutrientes digestíveis totais.

Tabela 3. Médias e erro-padrão das médias de consumo de nutrientes das dietas com feno de capimbraquiária (Brachiaria brizantha cv. MG4) e silagens de grãos úmidos de milho e de sorgo, com ou sem inoculante microbiano, usadas para ovinos

\begin{tabular}{|c|c|c|c|c|c|}
\hline Nutriente & $\begin{array}{c}\text { Feno + milho } \\
\text { sem inoculante }\end{array}$ & $\begin{array}{c}\text { Feno }+ \text { milho } \\
\text { com inoculante }\end{array}$ & $\begin{array}{c}\text { Feno + sorgo } \\
\text { sem inoculante }\end{array}$ & $\begin{array}{l}\text { Feno + sorgo } \\
\text { com inoculante }\end{array}$ & $\begin{array}{l}\mathrm{CV} \\
(\%) \\
\end{array}$ \\
\hline CMS (g/dia) & $783,62 \pm 152,14$ & $809,87 \pm 56,75$ & $758,88 \pm 80,20$ & $695,10 \pm 92,48$ & 20,94 \\
\hline CMS (\%PV) & $1,97 \pm 0,42$ & $2,00 \pm 0,11$ & $1,90 \pm 0,28$ & $1,73 \pm 0,26$ & 18,93 \\
\hline $\mathrm{CMS}\left(\mathrm{g} / \mathrm{kgPV}^{0,75}\right)$ & $49,28 \pm 10,29$ & $50,57 \pm 2,75$ & $47,75 \pm 6,47$ & $43,73 \pm 6,35$ & 19,07 \\
\hline CMO (g/dia) & $747,79 \pm 146,18$ & $773,0 \pm 153,08$ & $722,78 \pm 75,74$ & $661,20 \pm 87,81$ & 20,91 \\
\hline CPB (g/dia) & $41,75 \pm 8,73$ & $40,80 \pm 4,07$ & $41,43 \pm 4,65$ & $38,91 \pm 5,48$ & 20,85 \\
\hline CEE (g/dia) & $20,51 \pm 2,63 a$ & $21,00 \pm 0,98 \mathrm{a}$ & $13,58 \pm 1,39 b$ & $12,44 \pm 1,60 \mathrm{~b}$ & 21,56 \\
\hline CFDN (g/dia) & $360,45 \pm 97,31$ & $372,77 \pm 26,79$ & $336,41 \pm 40,55$ & $308,18 \pm 46,56$ & 26,65 \\
\hline CCNE (g/dia) & $325,17 \pm 80,73$ & $334,51 \pm 22,13$ & $331,39 \pm 31,72$ & $301,66 \pm 41,45$ & 27,84 \\
\hline CCHOT (g/dia) & $685,61 \pm 89,02$ & $707,28 \pm 24,46$ & $667,81 \pm 36,13$ & $609,84 \pm 44,01$ & 21,47 \\
\hline CNDT (g/dia) & $499,84 \pm 67,82$ & $498,92 \pm 39,78$ & $488,09 \pm 38,94$ & $440,32 \pm 62,17$ & 19,10 \\
\hline
\end{tabular}

Médias seguidas por letras distintas na linha diferem entre si pelo teste Tukey $(\mathrm{P}<0,05)$.

MS: matéria seca; MO: matéria orgânica; PB: proteína bruta; EE: extrato etéreo; FDN: fibra em detergente neutro; CNE: carboidratos não estruturais; CHOT: carboidratos totais; NDT: nutrientes digestíveis totais. 
Valores de consumo das dietas contendo feno e silagens de grãos úmidos foram de 49,93 e $45,74 \mathrm{~g} / \mathrm{kg} \mathrm{PV} \mathrm{PV}^{0,75} \mathrm{e}$, em porcentagem de peso vivo, foram 1,99 e $1,82 \% \mathrm{PV}$, respectivamente, para dietas com silagens de grãos úmidos de milho e de sorgo. As médias de CMS obtidas com o fornecimento das dietas contendo feno de capim-braquiária e silagens de grãos úmidos foram semelhantes às recomendações do AFRC (Energy..., 1993), que consistem em consumo mínimo entre 600 e $800 \mathrm{~g}$ de $\mathrm{MS} /$ dia para animais entre 30 e $40 \mathrm{~kg}$ de PV.

As médias de consumo de nutrientes das silagens, em função dos tratamentos, são apresentadas na Tab. 4. Não houve interação significativa $(\mathrm{P}>0,05)$ de grão (milho ou sorgo) versus inoculante microbiano. $\mathrm{O}$ consumo de nutrientes não foi influenciado $(\mathrm{P}>0,05)$ pela espécie do grão ou pelo uso de inoculante, o que sugere que todas as silagens de grãos úmidos foram bem conservadas (Jobim e Reis, 2001).

Devido às diferenças nos teores de EE dos grãos úmidos de milho e de sorgo (Tab. 1), os animais que receberam a dieta com silagem de grãos úmidos de sorgo apresentaram menor CEE $(\mathrm{P}<0,05)$. Mizubuti et al. (2002) encontraram maior consumo de EE por ovinos alimentados com silagem da parte aérea de milho, 53,10g/dia, em comparação aos alimentados com silagem de parte aérea de sorgo, 34,97g/dia, devido ao menor teor de EE na composição da silagem de parte aérea de sorgo.

Tabela 4. Médias e erro-padrão das médias de consumos de nutrientes das silagens de grãos úmidos de milho e de sorgo, com ou sem inoculante microbiano, usadas para ovinos

\begin{tabular}{lccccc}
\hline Nutriente & $\begin{array}{c}\text { Milho } \\
\text { sem inoculante }\end{array}$ & $\begin{array}{c}\text { Milho } \\
\text { com inoculante }\end{array}$ & $\begin{array}{c}\text { Sorgo } \\
\text { sem inoculante }\end{array}$ & $\begin{array}{c}\text { Sorgo } \\
\text { com inoculante }\end{array}$ & $\begin{array}{c}\text { CV } \\
(\%)\end{array}$ \\
\hline CMS (g/dia) & $470,17 \pm 21,77$ & $485,92 \pm 20,05$ & $455,33 \pm 28,73$ & $417,06 \pm 59,36$ & 22,40 \\
CMS (\%PV) & $1,18 \pm 0,15$ & $1,20 \pm 0,03$ & $1,14 \pm 0,16$ & $1,04 \pm 0,13$ & 20,30 \\
CMS (g/kgPV & $29,75)$ & $30,34 \pm 0,66$ & $28,65 \pm 3,50$ & $26,24 \pm 3,33$ & 20,56 \\
CMO (g/dia) & $464,10 \pm 20,81$ & $479,80 \pm 19,33$ & $448,04 \pm 28,63$ & $409,55 \pm 57,53$ & 21,40 \\
CPB (g/dia) & $31,59 \pm 6,56$ & $34,21 \pm 2,08$ & $31,60 \pm 2,57$ & $29,90 \pm 0,96$ & 27,00 \\
CEE (g/dia) & $16,97 \pm 1,89 \mathrm{a}$ & $17,35 \pm 0,62 \mathrm{a}$ & $10,15 \pm 0,47 \mathrm{~b}$ & $9,30 \pm 0,47 \mathrm{~b}$ & 21,07 \\
CFDN (g/dia) & $110,07 \pm 21,48$ & $114,00 \pm 4,70$ & $93,93 \pm 5,93$ & $86,08 \pm 12,25$ & 22,68 \\
CCNE (g/dia) & $305,52 \pm 21,10$ & $314,20 \pm 13,28$ & $312,36 \pm 19,78$ & $284,23 \pm 40,59$ & 22,34 \\
CCHOT (g/dia) & $415,58 \pm 28,97$ & $428,19 \pm 20,37$ & $406,30 \pm 16,26$ & $370,31 \pm 48,19$ & 22,41 \\
CNDT (g/dia) & $369,29 \pm 27,89$ & $372,07 \pm 21,17$ & $365,61 \pm 16,62$ & $328,11 \pm 48,91$ & 25,37 \\
\hline
\end{tabular}

Médias seguidas por letras distintas na linha diferem entre si pelo teste Tukey $(\mathrm{P}<0,05)$.

MS: matéria seca; MO: matéria orgânica; PB: proteína bruta; EE: extrato etéreo; FDN: fibra em detergente neutro; CNE: carboidratos não estruturais; CHOT: carboidratos totais; NDT: nutrientes digestíveis totais.

Os coeficientes de digestibilidade dos nutrientes da dieta, em função dos tratamentos, são apresentados na Tab. 5. Não houve efeito das espécies (milho ou sorgo) e da inoculação $(\mathrm{P}>0,05)$ sobre a digestibilidade dos nutrientes. Rodrigues et al. (2002) não recomendaram a inoculação microbiana em silagens de parte aérea de milho, uma vez que silagens inoculadas não proporcionaram maior disponibilidade dos nutrientes, em ovinos. Schaefer et al. (1989), ao trabalharem com inoculação de silagens de grãos úmidos de milho em dietas de novilhos em terminação, não detectaram diferenças entre o consumo de MS e a digestibilidade de FDN e PB.

Os coeficientes de digestibilidade dos nutrientes das silagens, em função dos tratamentos, são apresentados na Tab. 6. Não houve diferença na digestibilidade da MS das silagens, com médias de 74,3 e 75,3\%, para as silagens de grãos úmidos de milho e de sorgo, respectivamente. Estes resultados diferem dos relatados por Sniffen (1980), que citou que o sorgo apresenta menor digestibilidade da PB que o milho, devido à maior porcentagem de endosperma periférico presente nos grãos de sorgo. 
Tabela 5. Médias e erro-padrão das médias de coeficientes de digestibilidade aparente dos nutrientes e nutrientes digestíveis totais (NDT) das dietas contendo feno de capim-braquiária (Brachiaria brizantha cv. MG4) e silagens de grãos úmidos de milho e de sorgo, com ou sem inoculante microbiano, usadas para ovinos

\begin{tabular}{lccccc}
\hline Nutriente & $\begin{array}{c}\text { Feno + milho } \\
\text { sem inoculante }\end{array}$ & $\begin{array}{c}\text { Feno + milho } \\
\text { com inoculante }\end{array}$ & $\begin{array}{c}\text { Feno + sorgo } \\
\text { sem inoculante }\end{array}$ & $\begin{array}{c}\text { Feno + sorgo } \\
\text { com inoculante }\end{array}$ & $\begin{array}{c}\text { CV } \\
(\%)\end{array}$ \\
\cline { 2 - 6 } DMS (\%) & $56,18 \pm 5,28$ & $55,85 \pm 1,06$ & $56,92 \pm 3,02$ & $56,31 \pm 4,22$ & 12,84 \\
DMO (\%) & $62,64 \pm 4,24$ & $60,59 \pm 0,95$ & $61,21 \pm 3,49$ & $60,12 \pm 3,81$ & 10,80 \\
DPB (\%) & $46,92 \pm 2,72$ & $39,98 \pm 6,38$ & $42,26 \pm 2,63$ & $42,28 \pm 9,79$ & 15,04 \\
DEE (\%) & $83,76 \pm 5,28$ & $84,33 \pm 1,06$ & $84,68 \pm 3,02$ & $86,98 \pm 4,22$ & 8,86 \\
DFDN (\%) & $40,77 \pm 6,11$ & $38,08 \pm 1,99$ & $40,50 \pm 5,70$ & $38,42 \pm 5,27$ & 11,50 \\
DCNE (\%) & $90,62 \pm 4,81$ & $89,92 \pm 4,42$ & $93,08 \pm 3,38$ & $93,19 \pm 1,12$ & 5,70 \\
DCHOT (\%) & $64,41 \pm 5,46$ & $62,60 \pm 3,20$ & $66,59 \pm 4,54$ & $65,51 \pm 3,19$ & 12,02 \\
NDT (\%) & $63,79 \pm 4,07$ & $61,60 \pm 0,81$ & $64,32 \pm 3,47$ & $63,35 \pm 3,72$ & 11,03 \\
\hline
\end{tabular}

MS: matéria seca; MO: matéria orgânica; PB: proteína bruta; EE: extrato etéreo; FDN: fibra em detergente neutro; CNE: carboidratos não estruturais; CHOT: carboidratos totais; NDT: nutrientes digestíveis totais.

Tabela 6. Médias e erro padrão das médias de coeficientes de digestibilidade aparente dos nutrientes e nutrientes digestíveis totais (NDT) das silagens de grãos úmidos de milho e de sorgo, com ou sem inoculante microbiano, usadas para ovinos

\begin{tabular}{lccccc}
\hline Nutriente & $\begin{array}{c}\text { Milho } \\
\text { sem inoculante }\end{array}$ & $\begin{array}{c}\text { Milho } \\
\text { com inoculante }\end{array}$ & $\begin{array}{c}\text { Sorgo } \\
\text { sem inoculante }\end{array}$ & $\begin{array}{c}\text { Sorgo } \\
\text { com inoculante }\end{array}$ & $\begin{array}{c}\text { CV } \\
(\%)\end{array}$ \\
\hline DMS (\%) & $74,54 \pm 7,02$ & $73,99 \pm 3,89$ & $75,78 \pm 4,28$ & $74,77 \pm 6,78$ & 13,58 \\
DMO (\%) & $79,48 \pm 5,77$ & $76,03 \pm 3,48$ & $77,22 \pm 4,32$ & $75,49 \pm 5,95$ & 12,50 \\
DPB (\%) & $53,29 \pm 2,37$ & $50,73 \pm 7,44$ & $46,95 \pm 3,12$ & $46,83 \pm 1,00$ & 26,19 \\
DEE (\%) & $84,06 \pm 3,74$ & $84,77 \pm 0,54$ & $85,53 \pm 1,99$ & $88,63 \pm 2,19$ & 11,70 \\
DFDN (\%) & $44,68 \pm 9,46$ & $35,92 \pm 2,10$ & $44,31 \pm 9,89$ & $36,84 \pm 6,42$ & 20,44 \\
DCNE (\%) & $88,76 \pm 1,99$ & $89,33 \pm 0,60$ & $92,72 \pm 0,68$ & $92,83 \pm 0,51$ & 3,65 \\
DCHOT (\%) & $79,49 \pm 4,69$ & $75,06 \pm 2,06$ & $81,53 \pm 8,96$ & $80,04 \pm 4,25$ & 7,06 \\
NDT (\%) & $78,54 \pm 6,46$ & $76,57 \pm 2,45$ & $80,30 \pm 2,63$ & $78,67 \pm 1,55$ & 8,22 \\
\hline
\end{tabular}

MS: matéria seca; MO: matéria orgânica; PB: proteína bruta; EE: extrato etéreo; FDN: fibra em detergente neutro; CNE: carboidratos não estruturais; CHOT: carboidratos totais; NDT: nutrientes digestíveis totais.

Mizubuti et al. (2002) não encontraram diferenças entre a digestibilidade da matéria seca das silagens de parte aérea de milho e de sorgo, com médias de 56,0 e 48,5\%, respectivamente, valores menores que os obtidos neste ensaio, devido às características nutricionais das silagens de grãos úmidos de milho e de sorgo.

Valores de DMS mais altos foram encontrados por Ítavo et al. (2003), ao verificarem o efeito da inoculação sobre a digestibilidade in vitro da matéria seca de silagens de grãos úmidos de milho, inoculadas ou não, com médias de 80,8 e $79,8 \%$, para as silagens sem e com inoculante, respectivamente. Os valores in vitro fornecem referência sobre as silagens de grãos, porém vale destacar que essa análise está sujeita a um menor número de variações em comparação ao método in vivo. Além disso, a época de plantio e colheita adotada neste experimento foi de safrinha, ao passo que Ítavo et al. (2003) estudaram a ensilagem dos grãos úmidos de milho no período das águas.

Passini et al. (2002), ao estudarem a digestibilidade, em bovinos, de dietas totais à base de grãos úmidos de milho ou de sorgo ensilados, verificaram que a substituição do grão úmido de milho pelo de sorgo em 0, 50 e $100 \%$ diminuiu linearmente $o$ teor de nutrientes digestíveis totais, com semelhança nas digestibilidades da PB, FDN e EE. Provavelmente, a semelhança entre tipos de grãos nesse ensaio está relacionada às variedades de milho e de sorgo, às condições edafoclimáticas e épocas de plantio e à colheita dos grãos. No estudo de parâmetros de fermentação ruminal em bovinos alimentados com grãos de milho ou de sorgo ensilados, Passini et al. (2003) verificaram que dietas com $100 \%$ de milho e $100 \%$ de sorgo apresentaram a mesma produção de ácidos graxos totais e 
valores de $\mathrm{pH}$ ruminal semelhantes, o que evidencia que pode haver semelhança na degradação ruminal desses alimentos e, consequentemente, dos produtos finais disponíveis ao metabolismo animal, os quais assumem papel preponderante na manutenção da ingestão da matéria seca e da digestibilidade de nutrientes.

Somado a isso, o estádio de maturação dos grãos na colheita para a ensilagem, provavelmente, pode ter favorecido a digestibilidade das silagens, pelo fato de a matriz proteica, que envolve os grânulos de amido, não estar completamente formada. De acordo com Phillipeau et al. (1999), a matriz proteica limita a digestão ruminal do amido, o que faz com que a colheita antecipada possa favorecer a disponibilidade do amido. Jobim e Reis (2001), em revisão, citaram que a colheita do grão úmido para silagem constitui uma vantagem, pois pode exercer efeito benéfico sobre a digestibilidade da matéria seca, devido ao fato de a matriz proteica não estar totalmente formada.

O amido da silagem de grão úmido de sorgo apresentou mesma digestibilidade que o amido do milho. Provavelmente, a facilidade de digestão dos grânulos de amido do sorgo deve-se à sua constituição rica em amilopectina, pois, segundo Jobim et al. (2001), maiores proporções de amilose, em relação à amilopectina, nos grãos de cereais, podem influenciar negativamente a taxa de degradação e a digestibilidade do amido, representadas pelos carboidratos não estruturais. Tais relatos podem reforçar a hipótese da semelhança entre as silagens de grãos úmidos de milho e de sorgo para a digestibilidade dos CNE (Tab. 6), o que também refletiu nos valores de NDT das dietas (Tab. 5) e das silagens (Tab. 6), fato que pode estar relacionado à teoria de Van Soest (1994), que citou que o amido do grão de sorgo apresenta $25 \%$ de amilose e $75 \%$ de amilopectina, enquanto o amido do grão de milho apresenta $28 \%$ de amilose e $72 \%$ de amilopectina, o que pode conferir certa vantagem no que diz respeito à digestibilidade do grão de sorgo.

\section{CONCLUSÕES}

O uso de inoculante microbiano em silagens de grãos úmidos de milho e de sorgo não se faz necessário, haja vista que a digestibilidade e o consumo de nutrientes, assim como o teor de nutrientes digestíveis totais, não foram influenciados pela inoculação. $\mathrm{O}$ grão de milho úmido pode ser substituído pelo grão de sorgo sem prejuízos ao desempenho de ovinos adultos.

\section{REFERÊNCIAS BIBLIOGRÁFICAS}

COSTA, C.; ARRIGONI, M.D.B.; SILVEIRA, A.C. et al. Silagem de grãos úmidos. In: SIMPÓSIO SOBRE NUTRIÇÃO DE BOVINOS, 7., 1999, Piracicaba. Anais... Piracicaba: FEALQ, 1999. p.69-87.

ENERGY and protein requirements of ruminants. Cambridge: Agricultural and Food Research Council, 1993. 159p.

HENDERSON, N. Silage additives. Anim. Feed Sci. Technol., v.45, p. 35-56, 1993.

ÍTAVO, C.C.B.F.; MORAIS, M.G.; ÍTAVO, L.C.V. et al. Composição e digestibilidade in vitro de silagens de grão úmido de milho com ou sem uso de aditivo microbiano. In: REUNIÃO ANUAL DA SOCIEDADE BRASILEIRA DE ZOOTECNIA, 40., 2003, Santa Maria. Anais... Santa Maria: SBZ, 2003. CD-ROM. Forragicultura. FOR-248 (Resumo).

JOBIM, C.C.; CECATO, U.; CANTO, M.W. Utilização de silagem de grãos de cereais na alimentação animal. In: SIMPÓSIO SOBRE PRODUÇÃO E UTILIZAÇÃO DE FORRAGENS CONSERVADAS, 1., 2001, Maringá. Anais... Maringá: CCA/UEM/DZO, 2001. p.146-176.

JOBIM, C.C.; REIS, R.A. Produção e utilização de silagem de grãos úmidos de milho. In: REUNIÃO ANUAL DA SOCIEDADE BRASILEIRA DE ZOOTECNIA, 38., 2001, Piracicaba. Anais... Piracicaba: SBZ, 2001. p.912-927.

McALLISTER, T.A.; FENIUK, R.; MIR, P. et al. Inoculants for alfafa silage: effects on aerobic stability, digestibility and the growth performance of feedlot steers. Livest. Prod. Sci., v.53, p.171-181, 1998.

MIZUBUTI, I.Y.; RIBEIRO, E.L.A.; ROCHA, M.A. et al. Consumo e digestibilidade aparente das silagens de milho (Zea mays L.), sorgo (Sorghum bicolor (L.) Moench) e girassol (Helianthus annuus L.). Rev. Bras. Zootec., v.31, p.267-272, 2002. 
PASSINI, R.; RODRIGUES, P.H.M.; CASTRO, A.L. et al. Parâmetros de fermentação ruminal em bovinos alimentados com grãos de milho ou sorgo de alta umidade ensilados. Rev. Bras. Zootec., v.32, p.1266-1274, 2003.

PASSINI, R.; SILVEIRA, A.C.; RODRIGUES, P.H.M. et al. Digestibilidade de dietas a base de grão úmido de milho ou sorgo ensilados em bovinos. In: REUNIÃO ANUAL DA SOCIEDADE BRASILEIRA DE ZOOTECNIA, 39., 2002, Recife. Anais... Recife: SBZ, 2002. CD-ROM. Nutrição de ruminantes. NUT-232 (Resumo).

PHILLIP, L.E.; FELLNER, V. Effects of bacterial inoculation of high-moisture ear corn on its aerobic stability, digestion, and utilization for growth by beef steers. J. Anim. Sci., v.70, p.3178-3187, 1992.

PHILIPPEAU, C.; MONREDON, F.D.; MICHALET-DOREAU, B. Relationship between ruminal starch and the physical characteristics of corn grain. J. Anim. Sci., v.77, p.238-243, 1999.

RODRIGUES, P.H.M.; ANDRADE， S.J.T.; RUZANTE, J.M. et al. Valor nutritivo da silagem de milho sob o efeito da inoculação de bactérias ácido-láticas. Rev. Bras. Zootec., v.31, p.2380-2385, 2002.

SCHAEFER, D.M.; BROTZ, P.G. ARP, S.C. et al. Inoculation of corn silage and high moisture corn with lactic acid bacteria and its effects on the subsequent fermentations and on feedlot performance of beef steers. Anim. Feed Sci. Technol., v.25, p.23-38, 1989.

SILVA, D.J.; QUEIROZ, A.C. Análise de alimentos - métodos químicos e biológicos. 3.ed. Viçosa: UFV, 2002. 235p.

SILVA, J.F.C., LEÃO, M.I. Fundamentos de nutrição de ruminantes. Piracicaba: Livroceres, 1979. 384p.

SNIFFEN, C.J. The use of by-pass protein in ration formulation. In: AMERICAN FEED MANUFACTURE ASSOCIATION NUTRITION COUNCIL, 40., New York. Proceedings... New York:1980. p.40.

SNIFFEN， C.J.; O'CONNOR， J.D.; VAN SOEST, P.J et al. A net carbohydrate and protein system for evaluating cattle diets. 2. Carbohydrate and protein availability. J. Anim. Sci., v.70, p.3562-3577, 1992.

VAN SOEST, P.J. Nutritional ecology of the ruminant. 2.ed. Ithaca: Comstock Publ. Assoc., 1994. 476p.

VIEIRA, F.A.P.; BORGES, I.; STEHLING, C.A.V. et al. Qualidade de silagens de sorgo com aditivos. Arq. Bras. Med. Vet. Zootec., v.56, p.764-772, 2004.

VILELA, D. Aditivos para silagem de plantas de clima tropical. In: REUNIÃO ANUAL DA SOCIEDADE BRASILEIRA DE ZOOTECNIA, 34., 1998, Botucatu. Anais... Botucatu: SBZ, 1998. p.73-108. 